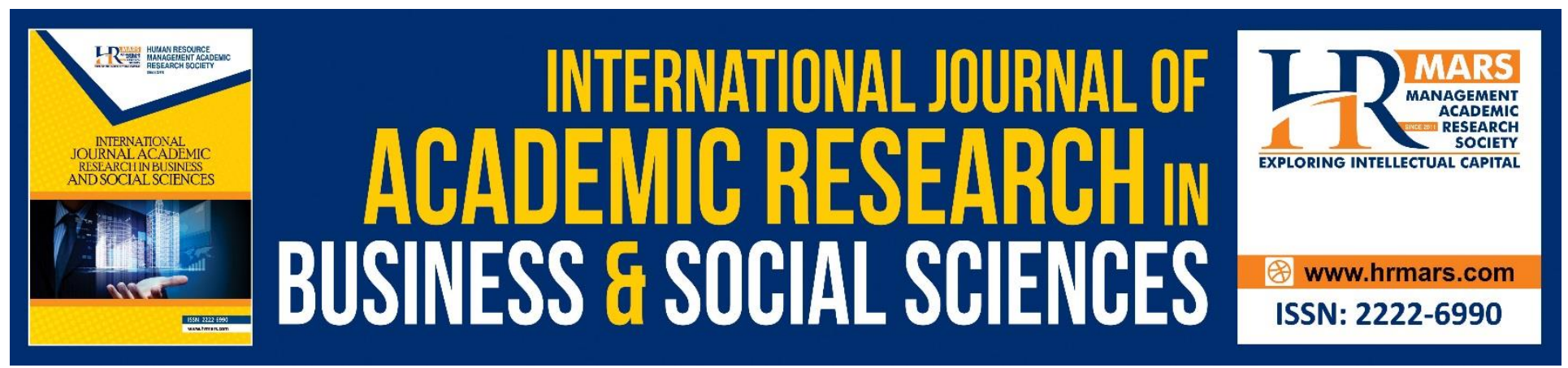

\title{
English Medium Instruction at Crossroads: Students' Voice and Way Forward
}

\section{Souba Rethinasamy, Joseph Ramanair, Kee-Man Chuah}

To Link this Article: http://dx.doi.org/10.6007/IJARBSS/v11-i14/8533

DOI:10.6007/IJARBSS/v11-i14/8533

Received: 11 November 2020, Revised: 14 December 2020, Accepted: 10 January 2021

Published Online: 29 January 2021

In-Text Citation: (Rethinasamy et al., 2021)

To Cite this Article: Rethinasamy, S., Ramanair, J., \& Chuah, K.-M. (2021). English Medium Instruction at Crossroads: Students' Voice and Way Forward. International Journal of Academic Research in Business and Social Sciences, 11(14), 109-123.

Copyright: (C) 2021 The Author(s)

Published by Human Resource Management Academic Research Society (www.hrmars.com)

This article is published under the Creative Commons Attribution (CC BY 4.0) license. Anyone may reproduce, distribute, translate and create derivative works of this article (for both commercial and non-commercial purposes), subject to full attribution to the original publication and authors. The full terms of this license may be seen at: http://creativecommons.org/licences/by/4.0/legalcode

Special Issue: Contemporary Business and Humanities Landscape Towards Sustainability, 2021, Pg. 109 - 123 http://hrmars.com/index.php/pages/detail/IJARBSS JOURNAL HOMEPAGE

Full Terms \& Conditions of access and use can be found at http://hrmars.com/index.php/pages/detail/publication-ethics 


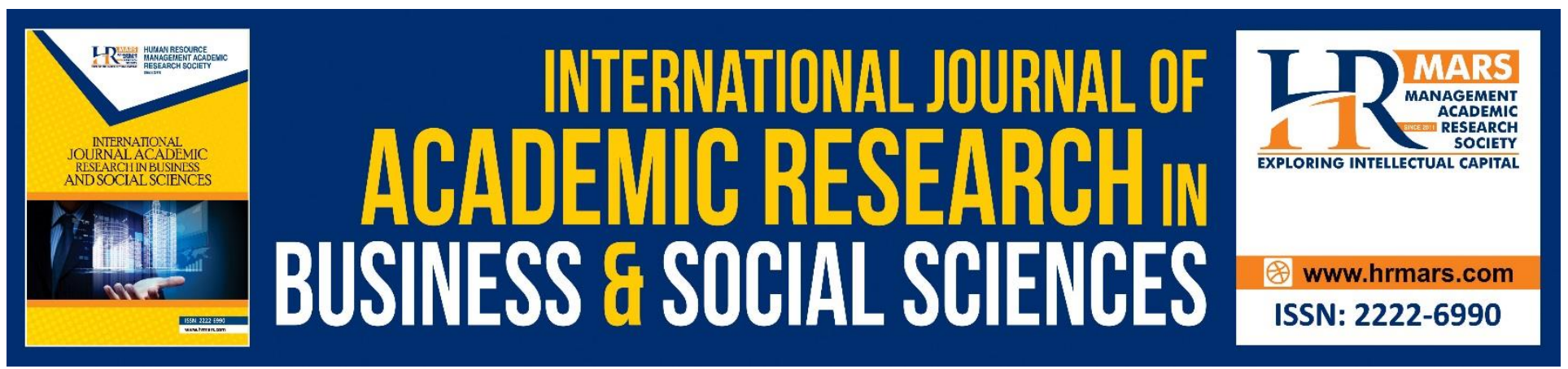

\title{
English Medium Instruction at Crossroads: Students' Voice and Way Forward
}

\author{
Souba Rethinasamy, Joseph Ramanair, Kee-Man Chuah \\ Faculty of Language and Communication, Universiti Malaysia Sarawak, MALAYSIA \\ Email: rsouba@unimas.my
}

\begin{abstract}
Globalisation and extensive use of technology have enhanced the status of English as an international language and increased its value as an important commodity in various fields. This has encouraged the use of English in the teaching of content subjects especially those related to science and technology in many countries across Asia. This paper starts with an overview of English medium instruction policy in the region with an emphasis on the ongoing debate regarding the teaching and learning of Science and Mathematics in English in Malaysia. Drawing on data from a longitudinal study which utilized questionnaires and the paper presents empirical evidence on the learners' views and experience in learning Science in English, as well as their performance in the standardized national examination. The data gathered from a total of 1000 students from urban and rural schools in Sarawak, Malaysia, indicate the they have rather positive view about their ability in English, had positive experience in learning Science in English. Their positive view and experience conform to their performance in the subject. The results also correlate with the majority of the students' language preference for learning Science which is English and bilingual instruction in English and Bahasa Malaysia. The paper ends with a discussion on possible amicable options for medium instruction issues in ESL/EFL contexts.
\end{abstract}

Keywords: English Medium Instruction (EMI), English as an International Language (EIL), Bilingual Education

\section{Introduction}

English has become a language used not only for communication purposes between people whose first languages differ but also a pivotal medium for transmission of information and knowledge exchange. With the ever-increasing importance of English, it is of no surprise that the language is becoming even more integrated into the field of education across the globe (Lucktong \& Pandey, 2020; Tsai, 2019). The adoption of English as the medium of instruction at various levels of education is apparent (Coleman, 2006; Crystal, 2004). Many countries are compelled to review their educational policies and practices in order to ensure the education system remains competitive and relevant (Nunan, 2003). In addition, English as medium instruction (EMI) has become an area of 